\title{
EVALUASI PERCEPATAN PEMBANGUNAN PROYEK RUSUNAWA ASN PEMKAB MALANG MENGGUNAKAN METODE CRASHING DENGAN SISTEM SIHFT KERJA
}

\author{
Ninda Rizki Apriliana ${ }^{1}$, Amri Gunasti ${ }^{2}$, Totok Dwi Kuryanto ${ }^{3}$ \\ Fakultas Teknik, Universitas Muhammadiyah Jember \\ E-mail: nindarizka47@gmail.com
}

\begin{abstract}
In construction projects there are three things that must be considered, namely time, cost and quality. However, reality shows that there is still often a delay time of implementation. One way to overcome delay in construction projects is to do with the crashing. This research was conducted on the project of the construction of the building Rusunawa ASN Malang Regency. The method of crashing used by way of a work shift. The calculation of the needs of the work shift using the guidelines for the calculation of Unit Price Analysis of Workers (AHSP) in 2018. The results showed that the project can be accelerated for 24 working days, so the duration of the project which was originally 197 working days to 173 days of work. Direct costs the project has increased from Rp.12.763.192.497.58 in 197 days to Rp. 12.937.000.000.00 in 173 days (up 1,3554\%).
\end{abstract}

Keywords : Crashing, Unit Price Analysis of Workers 2018, shift work, and Rusunawa 


\section{PENDAHULUAN}

Keterlambatan pekerjaan proyek dapat diantisipasi dengan melakukan percepatan dalam pelaksanaannya namun harus tetap memperhatikan faktor biaya. (Frederika, 2010). Pertambahan biaya yang dikeluarkan diharapkan dapat seminimum mungkin dan tetap memperhatikan standart mutu.(Hendriputri, 2018).Hal ini dinilai sangat merugikan bagi para kontaktor dalam melaksanakan proyek-proyek tersebut. Tidak terkecuali di Malang, dalam pembangunan Rusunawa ASN Pemkab Malang ini juga mengalami keterlambatan yang cukup lama yakni 3 bulan atau 90 hari (kalender) di bandingkan dengan waktu pekerjaan normal yang hanya 197 hari, berarti keterlambatan pada proyek ini mencapai 287 hari (waktu keterlambatan di tambah dengan waktu pekerjaan normal). Hal ini disebabkan karena para pekerja mengalami masalah pada jam kerja yang kurang efektif sehingga menjadikan produktifitas pekerjaan kurang maksimal. Faktor cuaca yang tidak dapat di prediksi selama perkerjaan berlangsung juga menjadi penyebab keterlambatan pembangunan proyek Rusunawa ASN Pemkab Malang. Perbandingan waktu pekerjaan normal dan waktu keterlambatan dapat dilihat dari grafik tersebut:

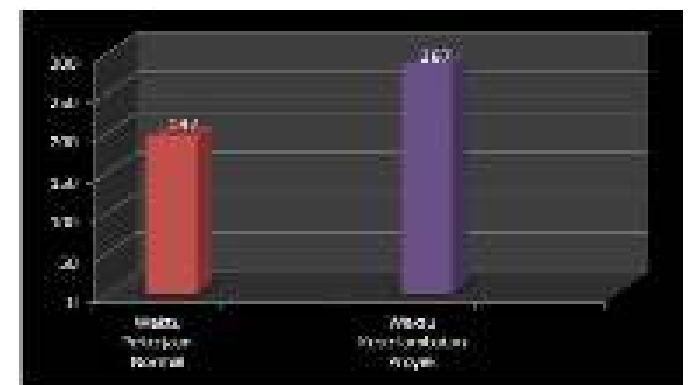

Gambar 1.1. Grafik Perbandingan Waktu Pekerjaan Normal dan Waktu Keterlambatan Pekerjaan di Proyek Rusunawa ASN Pemkab Malang
Untuk meminimalisir keterlambatan maka dilakukan percepatan penyelesaian proyek yang harus dilakukan dengan perencanaan yang baik. Alternatif yang biasa digunakan untuk menunjang percepatan aktifitas adalah dengan melakukan shift kerja, sehingga berpengaruh pada biaya total proyek (Nuhuyanan \& Sumarningsih, 2018). Untuk mengetahui hal ini perlu dipelajari tentang jaringan kerja yang ada,hal tersebut disebut sebagai Metode PDM (Precedence Diagram Method).

Permasalahan pada Proyek Pembangunan Rusunawa ASN Pemkab Malang dipilih sebagai objek penelitian karena mengalami keterlambatan pada pelaksanaannya. Untuk mengatasi keterlambatan tersebut, diperlukan upaya percepatan penyelesaian proyek dengan analisis menggunakan Metode crashing denagn sistem shift kerja. Maksudnya adalah mempercepat waktu pelaksanaan proyek menggunakan shift kerja (shift pagi dan shift malam) dan menganalisis sejauh mana waktu dapat dipersingkat dengan penambahan biaya terhadap kegiatanyang bisa dipercepat dan kurun waktu pelaksanaannya sehingga dapat diketahui percepatan waktu dan biaya yang di inginkan.

\section{METODE}

\section{Tahap-Tahap Network Planning}

Aplikasi atau penerapan network planning pada penyelenggaraan proyek memerlukan persyaratan yang harus dipenuhi agar dapat dilaksanakan dengan baik (Soeharto, 1999). Jika sudah ada ketetapan mengenai proyek yang akan dilaksanakan, maka selanjutnya dilakukan tahap aplikasi network planning yang terdiri dari tiga kelompok yaitu: pembuatan desain, pemakaian desain, dan perbaikan desain (Frederika, 2010).

Proses menyusun jaringan kerja dilakukan secara berulang-ulang sebelum sampai pada suatu perencanaan atau jadwal yang dianggap 
cukup realistis (Supriyanto, 2019). Metode jaringan kerja memungkinkan aplikasi konsep management by exception, karena metode tersebut dengan jelas mengidentifikasikan kegiatan-kegiatan yang bersifat kritis bagi proyek, terutama dalam aspek jadwal dan perencanaan (Arija, 2017). Umumnya kegiatan kritis tidak boleh lebih dari $20 \%$ total kegiatan proyek, dengan telah diketahuinya bagian ini maka pengelola dapat memberikan prioritas perhatian pada network planning tersebut (Kastawan Mandala, 2018).

Tahap-tahap network planning secara ringkas dapat digambarkan sepertipada Gambar 2.1

\begin{tabular}{|lc|}
\hline $\begin{array}{l}\text { Identifikasi lingkup } \\
\text { menguraikannya }\end{array}$ & $\begin{array}{c}\text { proyek dan } \\
\text { menjadikomponen- } \\
\text { komponen kegiatan. }\end{array}$ \\
\end{tabular}

Menyusun komponen-komponen kegiatan sesuai urutan logika ketergantungan menjadi jaringan kerja.

Memberikanperkiraankurunwaktu masing-masingpekerjaan.

Identifikasijalurkritis,float dan kurun waktu penyelesaian proyek.

Meningkatkandayagunadanhasilguna pemakaiansumberdaya.

Gambar2.1 Ringkasan langkah-langkah dalam

menyusun jaringan kerja (Sumber:Soeharto,1999)

\section{Penyusunan Network Planning dengan Metode Preseden Diagram}

Kegiatan dan peristiwa pada metode preseden diagram ditulis dalam node yang berbentuk kotak segiempat. Kotak-kotak tersebut menandai suatu kegiatan, dimana harus dicantumkan identitas kegiatan dan kurun waktunya (Oka Suputra, 2011). Sedangkan peristiwa merupakan ujung-ujung kegiatan. Setiap node memiliki dua peristiwa yaitu awal dan akhir. Pada preseden diagram hubungan antar kegiatan berkembang menjadi beberapa kemungkinan berupa konstrain. Konstrain menunjukkan hubungan antar kegiatan dengan satu garis dari node terdahulu kenode berikutnya. Satu konstrain hanya dapat menghubungkan dua node (Frederika, 2010). Karena setiap node memiliki dua ujung yaitu ujung awal atau mulai (S) dan ujung akhir (F), maka ada empat macam konstrain yaitu awal ke awal (SS), awalke akhir (SF), dan akhir ke awal(FS). Pada garis konstrain dibubuhkan penjelasan mengenai waktu mendahului (lead) atau terlambat / tertunda (lag). Bila kegiatan (i) mendahului kegiatan (j) dan satuan waktu adalah hari (Frederika, 2010).

\section{Perhitungan Metode PDM}

Parameter yang digunakan dalam perhitungan metode PDM akan dijelaskan sebagai berikut (Oka Suputra, 2011):

- $\mathrm{TE}=\mathrm{E}$, adalah waktu paling awal peristiwa (node/event) dapat terjadi (earliesttimeofoccurrence).

- $\mathrm{TL}=\mathrm{L}$, adalah waktu paling akhir peristiwa boleh terjadi (latestallowable eventoccurrencetime).

- ES adalah waktu mulai paling awal suatu kegiatan (earlieststarttime).

- EF adalah waktu selesai paling awal suatu kegiatan (earliestfinishtime).

- LS adalah waktu paling akhir kegiatan boleh dimulai (latestallowable starttime)

- LF adalah waktu paling akhir kegiatan 
boleh selesai (latestallowable finishtime).

- $\mathrm{D}=$ Durasi, adalah kurun waktu suatu kegiatan, umumnya dengan satuan waktu hari, minggu, bulan, dan lain-lain.

Tenggang waktu total (TotalFloat) adalah jumlah waktu tenggang yang didapat bila semua kegiatan yang mendahuluinya dimulai pada waktu sedini mungkin dan semua kegiatan yang mengikutinya terlaksana pada waktu yang paling lambat (Qomariyah \& Hamzah, 2013). Rumusan yang akan dipakai dalam perhitungan waktu pada penyusunan network planning dengan metode preseden diagram adalah sebagai berikut:

\section{Hitungan maju}

Rumusan perhitungan waktu maju adalah sebagai berikut (Caesaron \& Thio, 2015):

- Waktu mulai paling awal dari kegiatan yang sedang ditinjau ES (j), adalah sama dengan angka terbesar dari jumlah angka kegiatan yang terdahulu ES (i) atau EF (i) ditambah konstrain yang bersangkutan.

- Angka waktu selesai paling awal kegiatan yang sedang ditinjau WF (j), adalah sama dengan angka waktu mulai paling awal kegiatan tersebut ES (j), ditambah kurun waktu kegiatan yang bersangkutan D (j).

\section{Hitungan mundur}

Rumusan perhitungan waktu mundur adalah sebagai berikut (Caesaron \& Thio, 2015):

- Hitung LF (i), waktu selesai paling akhir kegiatan (i) yang ditinjau, yang merupakan angka terkecil dari jumlah kegiatan LS dan LF ditambah konstrain yang bersangkutan. Waktu mulai paling akhir kegiatan yang

- sedang ditinjau LS (i), adalah sama dengan waktu selesai paling akhir kegiatan tersebut LF (i), dikurangi kurun waktu yang bersangkutan.

- Jalur dan kegiatan kritis pada jalur dan kegiatan kritis metode preseden diagram sebagai berikut:
- Waktu mulai paling awal dan akhir harus sama (ES = LS).

- Waktu selesai paling awal dan akhir harus sama $(\mathrm{EF}=\mathrm{LF})$.

- Kurun waktu kegiatan adalah sama dengan perbedaan waktu selesai paling akhir dengan waktu mulai paling awal (LF- ES=D).

- Bila hanya sebagian kegiatan bersifat kritis, maka kegiatan tersebut secara utuh dianggap kritis.

\section{Percepatan Durasi Penyelesaian Proyek (Crashing)}

Pelaksanaan proyek. Besarnya/jumlah umur proyek samadengan besarnya/jumlah waktu yang ada pada suatu lintasan kritis(Irwan, 2019). Percepatan pelaksanaan pekerjaan berarti upaya memperpendek lintasan kritis pada jaringan rencanakerja yang bersangkutan. Sementara menurut (Rama et al., 2016). Tujuan utama dari program mempersingkat waktu adalah memperpendek jadwal penyelesaian kegiatan atau proyek dengan kenaikan biaya minimal.

Untuk menganalisis lebih lanjut hubungan antara waktu dan biaya suatu kegiatan, maka dipakai definisi sebagai berikut:(Setiawan et al., 2012)

1. Kurun waktu normal adalah kurun waktu yang diperlukan untuk melakukan kegiatan sampai selesai, dengan cara yang efisien tetapi diluar pertimbangan adanya kerja lembur dan khusus lainnya, seperti menyewa peralatan lebih canggih.

2. Biaya normal adalah biaya langsung yang diperlukan untuk menyelesaikan kegiatan dengan kurun waktu normal.Terdapat biaya normal bahan dan biaya normal upah.

3. Kurun waktu dipersingkat (Crash time) adalah waktu tersingkat untuk menyelesaikan suatu kegiatan yang secara teknis masih mungkin. Disini 
dianggap sumber daya bukan merupakan hambatan.

4. Biaya untuk waktu dipersingkat (Crash cost) adalah jumlah biaya langsung untuk menyelesaikan pekerjaan dengan kurun waktu tersingkat.

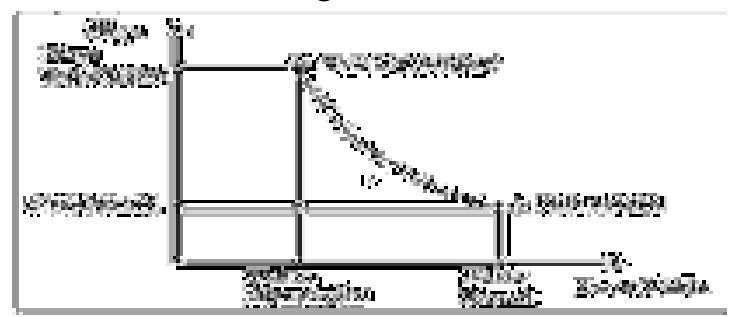

Gambar 2.2 Hubungan waktu-biaya normal dan dipersingkatuntuk satu kegiatan.

(Sumber : Iman Soeharto, 1999)

Titik A pada Gambar 2.1 menunjukkan titik normal, sedangkan titik $\mathrm{B}$ adalah titik dipersingkat. Garis yang menghubungkan titik A dengan B disebut kurva waktu-biaya. Pada umumnya garis ini dapat dianggap sebagai garis lurus, bila tidak (misalnya, cekung) maka diadakan perhitungan persegmen yang terdiri atas beberapa garis lurus. Seandainya diketahui bentuk kurva waktu-biaya suatu kegiatan, artinya dengan mengetahui berapa slope atau sudut kemiringannya, maka bisa dihitung berapa besar biaya untuk mempersingkat waktu satu hari.

Penambahan biaya langsung (direct cost) untuk mempercepat suatu aktivitas persatuan waktu disebut costslope. berikut:

Dari uraian diatas dapat ditulis sebagai

1. Rumus Biaya Normal :

Koefisien $=\frac{\text { Biaya Bahan } / \text { upah }}{\text { Biaya ahan dan upah }} \ldots . .$.

Total Biaya Normal = Koefisien x Biaya Normal x Volume pekerjaan
2. Rumus Durasi Crashing :

Durasi $\begin{gathered}\text { Crashing } \\ \text { Volume Pekerjaan }\end{gathered}=$

Kapasitas kerja shift $x$ jumlah tenaga kerja (2.2)

3. Rumus total upah tenaga kerja :

((upah shift pagi + upah shift malam) $\mathrm{x}$ durasi proyek $\mathrm{x}$ jumlah tenaga kerja))............................(2.3)

4. Rumus Cost Slope:

(slopebiaya) $\frac{\text { biaya dipersingkat-Biaya normal }}{\text { Waktu Normal-Waktu dipersingkat }} . . .$. ..(2.4)

5. Produktivitas pada shift kerja dihitung dengan rumus sebagai berikut:

Produktivitas Shift $=$ Prod. Kerja/ hari normal + (prod. Kerja/hr- (prod. Kerja/hr $\mathrm{x} 11 \%$

6. Menenentukan jumlah tenaga kerja yang akan digunakan dengan menggunakan rumus :

Jumlah Tenaga Kerja $=$

$\frac{\text { Volume Pekerjaan }}{\text { Kapasitas kerja t } x \text { Durasi Pekerjaan }} \ldots . .$.
$\ldots \ldots \ldots \ldots \ldots \ldots \ldots$ (2.6)

\section{HASIL DAN PEMBAHASAN}

Penjadwalan Proyek dengan Pendekatan Metode PDM

PDM merupakan salah satu bentuk penyajian grafis dari rencana kegiatan proyek selain metode CPM atau ADM. PDM digambarkan dalam bentuk segiempat dan dihubungkan dengan anak panah. Penggunaan PDM sangat efektif untuk pekerjaan yang sifatnya berulang, atau aktifitas yang dilakukan secara bersamaan karena aktivitas yang sama dan berulang akan dimasukkan dalam satu aktivitas namun harus menggunakan beberapa tipe hubungan antar aktivitas, seperti misalnya start to start atau finish to finish.Dalam melakukan penjadwalan langkah pertama yang harus 
dilakukan adalah dengan menentukan item pekerjaan dengan durasi normal yang didapat dari data sebagai tabel berikut:

\section{Menentukan Hubungan Antar Kegiatan}

Penggambaran PDM dapat dilakukan dengan menggunakan satu atau lebih dari empat jenis hubungan kegiatan, yaitu:

\section{Hubungan Finish to Start (FS)}

Hubungan FS menunujukkan suatu hubungan ketergantungan dimana start dari suatu kegiatan tergantung pada finish kegiatan lain. Gambar 3.1 menunjukkan hubungan antara item pekerjaan nomor 7 ( Pekerjaan tiang pancang) dengan item pekerjaan nomor 9 (Pekerjaan Pemotongan Kepala tiang), pekerjaan pemotongan kepala tiang dimulai setelah pekerjaan tiang pancang selesai.

\begin{tabular}{|c|c|c|c|c|}
\hline Es & c5 & \multirow[b]{2}{*}{ is } & 52 & $\pi$ \\
\hline Rem Pek & 7 & & Rem Pek & 9 \\
\hline 71 & 5 & & $\pi$ & $\bar{D}$ \\
\hline
\end{tabular}

Gambar 3.1 PDM Bentuk 1 dengan Jenis Hubungan FS

\section{Hubungan Finish to Finish (FF)}

Hubungan FF menunjukkan suatu hubungan ketergantungan dimana finish dari suatu kegiatan tergantung pada finish kegiatan yang lain. Gambar 3.2 menunjukkan bahwa pekerjaan nomor 7 memiliki hubungan FF dengan pekerjaan nomor 9, karena kedua jenis pekerjaan tersebut merupakan suatu pekerjaan yang harus diselesaikan secara bersamaan.
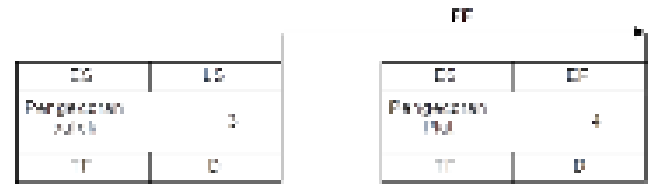

Gambar 3.2 PDM Bentuk 1 dengan Jenis Hubungan FF

\section{Hubungan Start to Finish (SF)}

Hubungan SF menunjukkan suatu hubungan ketergantungan dimana finish dari suatu kegiatan tergantung pada start kegiatan lain. Gambar 3.3 menunjukkan bahwa item pekerjaan nomor 9 tidak dapat selesai sampai sekian hari setelah item pekerjaan nomor 7 dimulai.

\begin{tabular}{cc}
\hline$y$ & is \\
\hline IIEI fod & $?$ \\
\hline$\pi$ & 0 \\
\hline
\end{tabular}

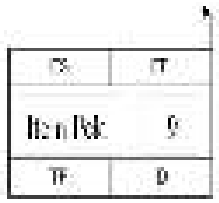

Gambar 3.3 PDM Bentuk 1 dengan Jenis Hubungan SF

4.Hubungan Start to Start (SS)

Hubungan ketergantungan dimana suatu kegiatan harus dimulai bersamaan dengan kegiatan lain seperti gambar 3.4.

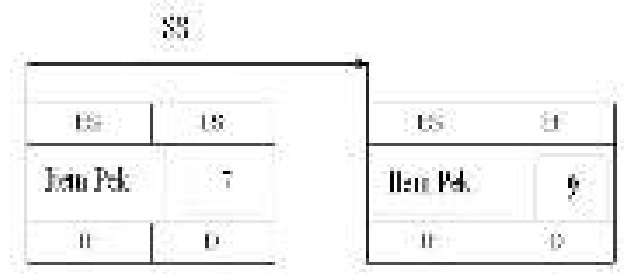

Gambar 3.4 PDM Bentuk 1 dengan jenis Hubungan SS

5.Hubungan Lead Time dan Lag Time

a. Lead Time terjadi bila terjadi penumpukan waktu antara selesainya suatu kegiatan dengan dimulainya kegiatan lain seperti gambar 3.5

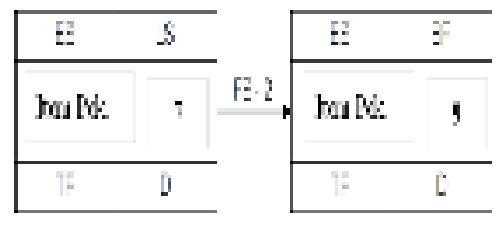

Gambar 3.5 PDM Bentuk 1 dengan adanya Lead Time

b. Lag Time merupakan tenggang waktu antara selesainya satu pekerjaan dengan dimulainya suatu kegiatan lain seperti gambar 3.6. 


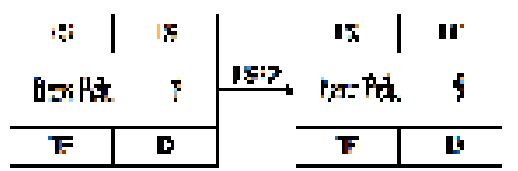

Gambar 3.6 PDM Bentuk 1 dengan adanya Lag Time

Tabel.3.1 Penentuan hubungan jaringan kerja dalam bentuk kegiatan sebelumnya (prodesessor)

\begin{tabular}{cccc}
\hline No & Item Pekerjaan & $\begin{array}{c}\text { Durasi } \\
\text { (hari) }\end{array}$ & Prodesessor \\
\cline { 2 - 4 } 20 & Pekerjaan pilecap & & \\
\cline { 2 - 4 } 20 & Bekisting & 15 & $\begin{array}{c}18 \mathrm{SS}+ \\
5 \text { days }\end{array}$ \\
\cline { 2 - 4 } 21 & Pembesian & 14 & $\begin{array}{c}\text { 20 SS }+2 \\
\text { days }\end{array}$ \\
\hline 22 & Pengecoran & 7 & 21 \\
\hline$\ldots$ & $\ldots \ldots \ldots \ldots \ldots \ldots$ & $\ldots \ldots \ldots$ & $\ldots$ \\
\hline$\ldots$ & $\ldots \ldots \ldots$ & $\ldots \ldots \ldots$ & $\ldots$ \\
\hline
\end{tabular}

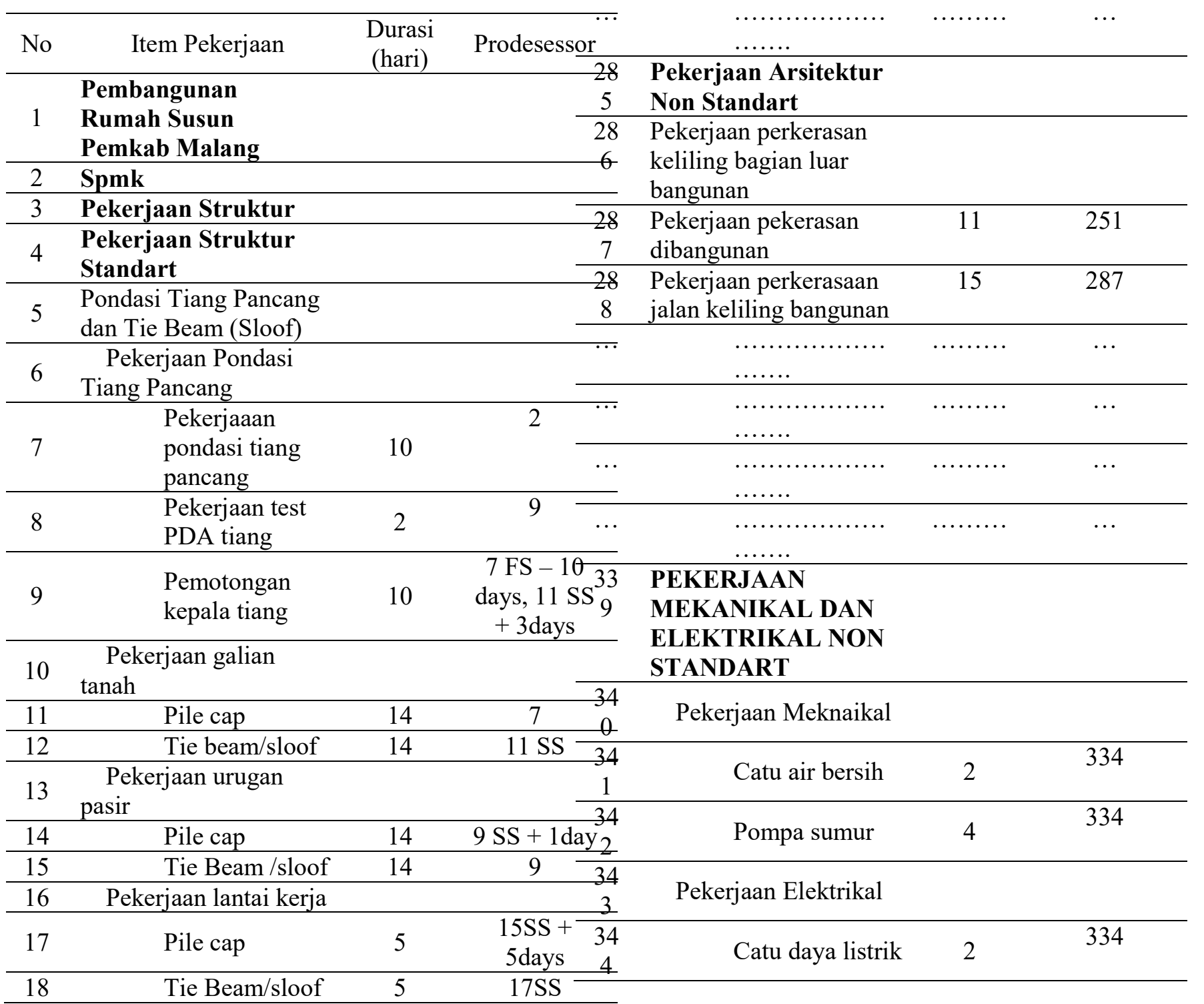




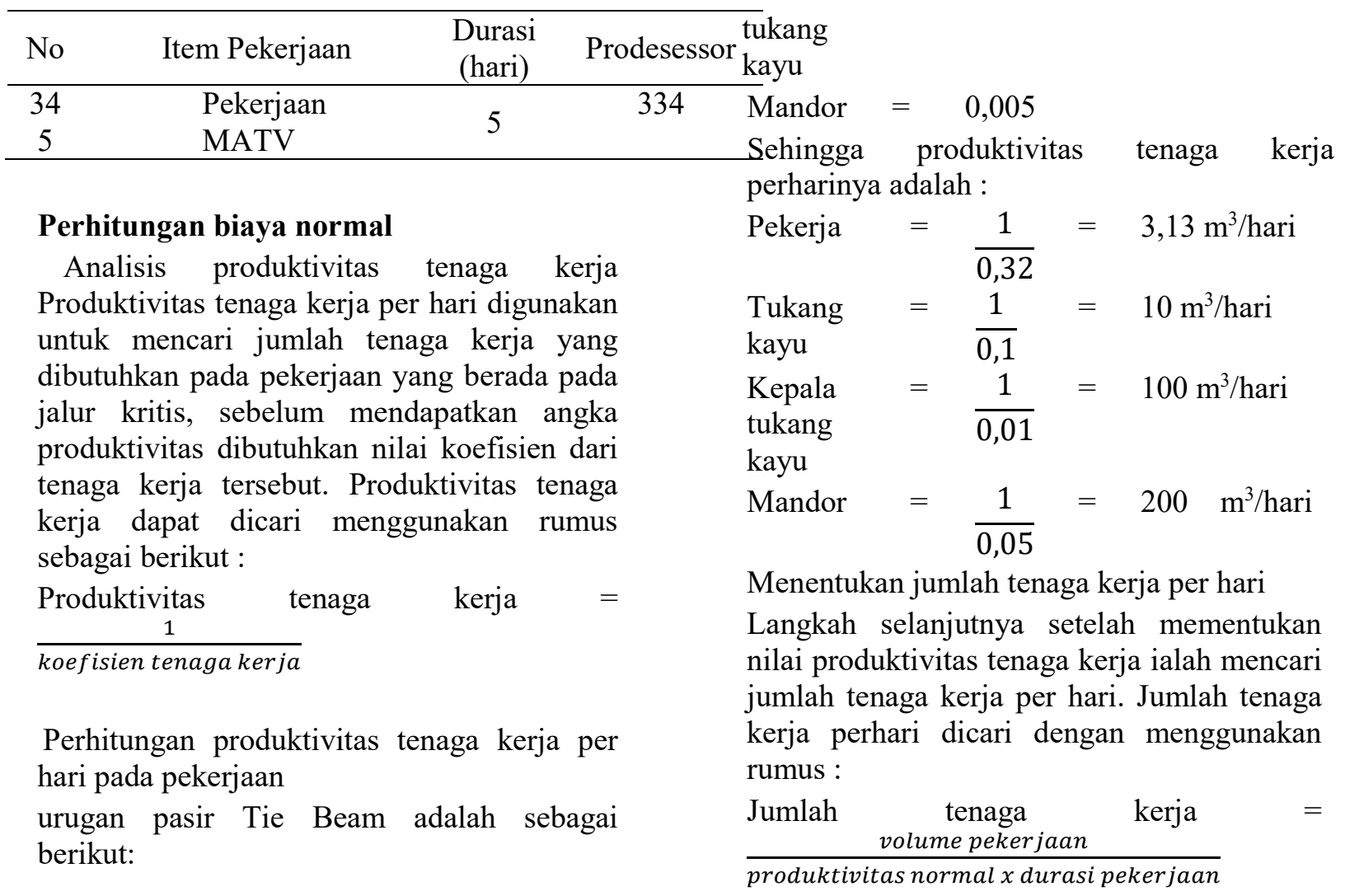

Diketahui Koefisien Tenaga kerja sebagai berikut:

$\begin{array}{lll}\text { Pekerja } & =0,4 \\ \text { Mandor } & =0,1\end{array}$

Sehingga produktivitas tenaga

kerja perharinya adalah

$\begin{aligned} \text { Pekerja }=\frac{1}{0,4} & \begin{array}{l}2,50 \\ \mathrm{~m}^{3} / \text { hari }\end{array} \\ \text { Mandor }=\frac{1}{0,1} & =10 \mathrm{~m}^{3} / \text { hari }\end{aligned}$

Perhitungan produktivitas tenaga kerja perhari pada pekerjaan bekisting Tie Beam adalah sebagai berikut:

Diketahui Koefisien Tenaga kerja sebagai berikut:

Pekerja $=0,32$
Tukang $=0,10$
kayu
Kepala $=0,01$

Jumlah tenga kerja per hari pada pekerjaan urugan pasir

$$
\begin{aligned}
& >\text { Volume }=16,11 \mathrm{~m}^{3} \\
& >\text { Durasi }=14 \text { hari } \\
& >\text { Pekerja }=16,11 /(14 \times 2,5)=0,4602 \mathrm{OH} \\
& >\text { Mandor }=16,11 /(14 \times 10)=0,115 \mathrm{OH}
\end{aligned}
$$

Jumlah tenaga kerja per hari pada pekerjaan bekisting tie

beam

$$
\begin{aligned}
> & \text { Volume }=610,44 \mathrm{~m} 2 \\
> & \text { Durasi }=10 \text { hari } \\
> & \text { Pekerja }=(610,44) /(10 \times 3,13)=19,5339 \mathrm{OH} \\
> & \text { Tukang Kayu }=(610,44) /(10 \times 10)=6,1044 \\
& \text { OH } \\
> & \text { Kepala T. Kayu }=(610,44) /(10 \times 100)= \\
& 0,614 \mathrm{OH} \\
> & \text { Mandor }=(610,44) /(10 \times 200)=0,3052 \\
& \mathrm{OH}
\end{aligned}
$$


Menghitung upah kerja per satuan pada pekerjaan normal

Untuk menghitung upah kerja per satuan pada pekerjaan normal, maka digunakan jumlah tukang pada pekerjaan normal. Rumus yang digunakan adalah sebagai berikut :

Harga $u p a h=$ volume $\mathrm{x}$ upah kerja per satuan

Harga upah total per satuan pada pekerjaan urugan pasir

$$
\begin{aligned}
> & \text { Pekerja }=15.600 \times 16,11=\operatorname{Rp~} 251.245,80 \\
> & \text { Mandor }=5.925 \times 16,11=\operatorname{Rp~} 95.425,09 \\
> & \text { Total }=\operatorname{Rp~346.670,888~}
\end{aligned}
$$

Harga upah total per satuan pada pekerjaan bekisting tie beam

$$
\begin{aligned}
& >\text { Pekerja }=610,44 \times 12.480=\mathrm{Rp} 7.618 .228,80 \\
& >\mathrm{T} . \mathrm{Kayu}=610,44 \times 4.725=\mathrm{Rp} 2.884 .305,38 \\
& >\text { KepalaTukang Kayu }=610,44 \times 502,5= \\
& \text { Rp 306.743,59 } \\
& >\text { Mandor }=610,44 \times 296,25=\mathrm{Rp} 180.841,37 \\
& >\text { Total }=\text { Rp10.990.110,131 }
\end{aligned}
$$

Adapun harga upah kerja per satuan didapat dari perhitungan AHSP sebagai berikut:

Nama pekerjaan : Urugan Pasir

Sub pekerjaan : All

Satuan : m3

Nama pekerjaan : Bekisting

Sub pekerjaan : Pile cape/ Tie beam (sloof)

Satuan : m2

Analisis Percepatan Durasi Penyelesaian Proyek

Analisis percepatan kali ini menggunakan sistem shift. Selanjutnya hasil dapat dibandingkan dengan biaya dan durasi proyek pada keaadan normal. Produktivitas masingmasing tenaga kerja per hari sudah diketahui sebelumnya dengan durasi kerja normal adalah delapan jam/ hari. Koefisien produktifitas pada sistem shift diambil angka $11 \%$ dari 11\%-17\% (Hanna, 2008) dan upah tenaga kerja shift malam akan ditambah $15 \%$ dari upah normal.
- Menentukan percepatan dengan shift pada pekerjaan urugan pasir

a. Menentukan produktivitas tenaga kerja dengan sistem shift

Produktivitas tenaga kerja shift $=$ Prod. Kerja/ hari normal + (prod. Kerja/hr- (prod. Kerja/hr x $11 \%)$

$>$ Pekerja $=2,5+(2,5-(2,5 \times 11 \%)=4,725$ $\mathrm{m} 3 /$ hari

$>$ Mandor $=10+(10-(10 \times 11 \%)=18,9$ $\mathrm{m} 3 /$ hari

b. Menentukan durasi kerja

durasi crashing = (volume pekerjaan)/(prod.tenaga kerja shift $\mathrm{x}$ jumlah tenaga kerja)

$>$ Pekerja $=16,11 /(4,725 \times 0,4602)=7,4074$

$>$ Mandor $=16,11 /(18,9 \times 0,115)=7,4074$

Maka di dapat durasi crashing selama $=8$ hari

c. Menentukan biaya tambahan dan upah kerja

Upah shift pagi

$>$ Pekerja $=$ Rp. 39000

Mandor $=$ Rp. 59250

Upah shift malam

((15\% x upah shift pagi $)+$ upah shift pagi)

$>$ pekerja $=(15 \%$ x 39000 $)+39000=\mathrm{Rp}$ 44.850

$>$ mandor $=(15 \% \times 59250)+59250=\mathrm{Rp}$ 68.137

Upah total tenaga kerja

Upah total $=$ upah shift pagi + upah shift malam

$>$ pekerja $=39000+44.850=\operatorname{Rp} 83.850$

$>$ mandor $=59250+68.137=\mathrm{Rp} \mathrm{127.387,5}$

Koefisien tenaga kerja

$>$ Pekerja $=1 / 2,5=0,4$

$>$ Mandor $=1 / 10=0,1$

Biaya upah tenga kerja per satuan

$>$ pekerja $=0,4 \times 83.850=\operatorname{Rp} 33.540$

$>$ mandor $=0,1 \times 127.387,50=\mathrm{Rp} 12.738,750$

Biaya upah tenaga kerja total

Upah tenaga kerja total $=$ upah tenaga kerja per satuan $\mathrm{x}$ volume

$>$ pekerja $=16,11 \times 33,540=\operatorname{Rp~540.178,470}$

$>$ mandor $=16,11 \times 12.738,750=\mathrm{Rp}$

205.163,408 
$>$ Total $=\operatorname{Rp} 745.342,408$

Cost Slope

Cost slope $=($ crash cost-normal cost $) /($ normal duration-crash duration)

$>$ Cost slope $/$ hari $=398.671,52 /(14-8)=\mathrm{Rp}$ $66.445,25$ / hari

$>$ Cost Slope total $=$ crash cost - normal cost

$$
\begin{aligned}
& =745.342,408-346.670,888 \\
& =\operatorname{Rp~398.671,52}
\end{aligned}
$$

d. Menentukan percepatan dengan shift pada pekerjaan bekisting tie beam.

Menentukan produktivitas tenaga kerja dengan sistem shift

Produktivitas tenaga kerja shift $=$

Prod. Kerja/ hari normal + (prod. Kerja/hr(prod. Kerja/hr x 11\%)

$>$ Pekerja $=3,13+(3,13-(31,13 \times 11 \%)=$ $5,90625 \mathrm{~m} 2 /$ hari

$>$ Tukang Kayu $=10+(10-(10 \times 11 \%)=$ $18,9 \mathrm{~m} 2 /$ hari

$>$ Kepala T.kayu $=100+(100-(100 \times 11 \%)$ $=189 \mathrm{~m} 2 /$ hari

$>$ Mandor $=200+(200-(200 \times 11 \%)=378$ $\mathrm{m} 2 /$ hari

e. Menentukan durasi kerja shift

Durasi crashing = (volume pekerjaan)/(prod.tenaga kerja shift $\mathrm{x}$ jumlah tebaga kerja)

$>$ Pekerja $=610,44 /(5,90625 \times 19,5339)$ $=5,291$

$>$ Tukang kayu $=610,44 /(18,9 \times 6,1044)$ $=5,291$

$>$ Kepala T.kayu $=610,44 /(189 \times 0,6104)$ $=5,291$

$>$ Mandor $=610,44 /(378 \times 0,3052)=5,291$

Maka di dapat durasi crashing selama $=6$ hari

f. Menentukan biaya tambahan dan upah pekerja

Upah shift pagi

$>$ pekerja

$=$ Rp. 39000

$>$ Tukang kayu

$=$ Rp. 47250

$>$ Kepala tukang kayu $=$ Rp. 50250
$>$ mandor $\quad=$ Rp. 59250
Upah shift malam
$>$ Pekerja $=(15 \% \times 39000)+39000=\mathrm{Rp}$ 44.850
$>$ Tukang kayu $=(15 \%$ x 47250) +47250 $=$ Rp. 54.338
$>$ Kepala T.kayu $=(15 \%$ x 50250) +50250 $=\operatorname{Rp} 57.788$
$>$ Mandor $=(15 \% \times 59250)+59250=\mathrm{Rp}$ 68.138

Upah total tenaga kerja

Upah total = upah shift pagi + upah shift malam

$>$ Pekerja $=39.000+44.850=\operatorname{Rp} 83.850$

$>$ Tukang kayu $=47.250+54.337,50=\mathrm{Rp}$ 101.587

$>$ Kepala T.kayu $=50 \cdot 250+57.787,50=$ Rp 108.037,50

$>$ Mandor $=59250+68.137=\mathrm{Rp} 127.387,5$

g. Menentukan Koefisien tenaga kerja

$>$ pekerja $=1 /(5,90625)=0,32$

$>$ Tukang kayu $=1 / 10=0,1$

$>$ Kepala tukang kayu $=1 / 100=0,01$

$>$ Mandor $=1 / 200=0,005$

Biaya upah tenaga kerja per satuan

$>$ Pekerja $=0,32 \times 83.850=\operatorname{Rp} 26.832$

$>$ Tukang kayu $=0,1 \times 101.587,50=\mathrm{Rp}$ $10.158,750$

$>$ Kepala T.kayu $=0,01 \times 108.037,50=\mathrm{Rp}$ $1.080,375$

mandor $=0,1 \times 127.387,50=R p 12.738,750$

Biaya upah tenaga kerja total

Upah tenaga kerja total $=$ upah tenaga kerja persatuan $\mathrm{x}$ voulume

$>$ Pekerja $=610,44 \times 26.832=$

Rp.16.379.191,920

$>$ Tukang kayu $=610,44 \times 101.587,50=\mathrm{Rp}$. 6.201.256,556

$>$ Kepala T.kayu $=610,44 \times 1.080,375$ $=$ Rp. 659.498,713

$>$ Mandor $=610,44 \times 1.080,375=\mathrm{Rp} .388 .808$, 943

$>$ Total $=$ Rp.23.628.756,132 
Cost Slope

Cost slope

$=($ crash cost-normal

cost)/(normal duration-crash duration)

$>$ Cost slope $/$ hari $=12.638 .637 /(10-6)=$ 3.159.659,25/hari

$>$ Cost Slope total $=$ crash $\operatorname{cost}-$ normal cost

$$
\begin{aligned}
& =23.628 .756 .132-10.990 .119,131 \\
& =\text { Rp. 12.638.637 }
\end{aligned}
$$

\section{Perbandingan Durasi Crashing terhadap Durasi Normal}

Durasi normal dapat menghasbiskan waktu pekerjaan selama 197 hari sedangkan hasil perhitungan crashing dapat mengefisiensikan pekerjaan sebesar 24 hari yaitu pekerjaan setelah di crashing menjadi 173 hari. Perbandingan Biaya terhadap Durasi Normal dan Durasi Crashing. Seiring dengan waktu yang dipercepat dapat berdampak pula pada penambahan biaya agar percepatan tersebut dapat terlaksana, adapun grafik perbandingan biaya normal dan biaya crashing termasuk durasi pekerjaan adalah sebagai berikut:

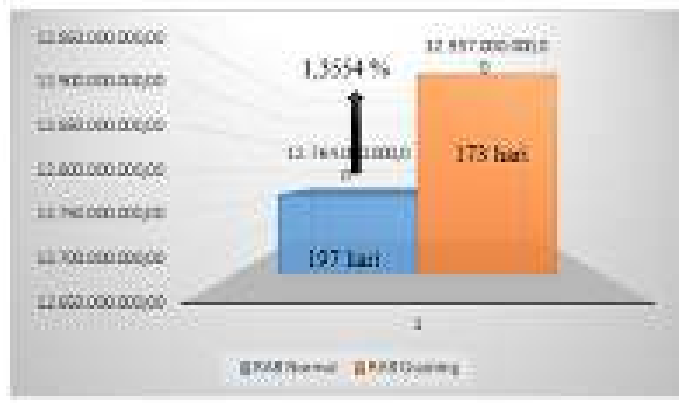

Dari gambar diatas dapat disimpulkan bahwa dengan dipercepatnya waktu pekerjaan akan menimbulkan peningkatan biaya. Dimana pada pekerjaan yang dilakukan normal (tanpa percepatan) dapat diselesaikan dalam waktu 197 hari dengan biaya Rp.12.764.000.00. sedangkan jika dilakukan peercepatan dengan shift kerja maka diaya pekerjaan akan menjadi Rp. 12.973.000.00 yaitu meningkat sebesar $1,3554 \%$ dari biaya normal namun waktu penyelesaian menjadi lebih singkat yakni menjadi 173 hari.
Dari hasil data pada penelitian ini ternyata tidak sesuai dengan penelitian terdahulu yang diteliti oleh caesaron (2015), karena pada penelitian yang saya teliti untuk hasil dari percepatan crashing dengan sistem shift kerja ini biaya yang di dapat mengalami peningkatan daripada biaya normal pada proyek tersebut, namun pada penelitian terdahulu ini total biaya setelah dilakukan percepatan crashing mengggunakan alternatif penambahan tenaga kerja malah terjadi penurunan biaya yang semula sebesar Rp. 884.420 .000 , namun mengalami penurunan total cost sebesar Rp 857.260.000.

Dari hasil data pada penelitian ini ternyata tidak sesuai dengan penelitian terdahulu yang diteliti oleh Frederika (2010), Karena pada penelitian yang saya teliti hasil dari percepatan crashing menggunakan sistem shift kerja biaya yang diperoleh mengalami peningkatan dari biaya normal pada proyek. Namun pada penelitian terdahulu ini juga menggunakan alternatif penambahan jam kerja dan juga diperoleh pengurangan total biaya sebesar Rp.1.012.856.772,54 dari total biaya normal Rp.90.620.898.879,84 menjadi Rp. 89.608.042.176,30 dengan durasi 392 hari. Sementara untuk alternatif penambahan shift kerja terjadi pengurangan total biaya sebesar Rp.1.240.225.176,44 dari total biaya normal Rp.90.620.898.879,84 menjadi Rp. 89.380.673.703,40 dengan durasi 382 hari.

Dari hasil data pada penelitian ini ternyata sesuai dengan penelitian terdahulu yang diteliti oleh Hendriputri (2018) dari penelitian terdahulu didapatkan hasil total biaya normal cost sebesar Rp 1.246.452.397,63. Dalam durasi 345 hari, namun pada percepatan crashing dengan menambahkan shift kerja didapakan total biaya Rp. 1.334.123.725,93 dengan durasi 191 hari, atau naik sebesar 7,03\%. Hal ini dikarenakan adanya penambahan kerja shift yang mengakibatkan terjadinya penambahan biaya pada pekerjaan tersebut.

Dari hasil data pada penelitian ini 
ternyata sesuai dengan penelitian terdahulu yang diteliti oleh Nuhuyanan, T. T., \& Sumarningsih, T. (2018) Dampak yang ditimbulkan akibat perubahan waktu terhadap biaya ini ialah naiknya jumlah biaya langsung (direct cost) yang semula berjumlah Rp1.292.145.054,00 dalam 120 hari menjadi Rp 1,296.520.471.00 dalam 106 hari. Sementara itu karena durasi proyek setelah dilakukan crashing menjadi singkat menyebabkan turunnya biaya tidak langsung (Indirect cost) yang semula Rp 143.571.672,00 jadi Rp 136.871.661,00 ada selisih Rp $6.700 .011,00$. Naiknya biaya langsung dan berkurangnya biaya tidak langsung itu menyebabkan biaya total proyek juga mengalami perubahan, yang semula Rp1.435.716.727,00 menjadi Rp1.433.392.132,00.

Kesimpulan yang dapat diperoleh dari uraian diatas adalah adanya penambahan dan pengurangan biaya pada proses percepatan crashing dengan beberapa alternatif yang sudah disebutkan di atas. Namun dari alternatif diatas adalah penggunaan sistem shift memang paling efisien hal itu terjadi karena adanya pengurangan jumlah waktu yang terjadi saat di adakan sistem shift pada suatu proyek.

\section{KESIMPULAN}

Berdasarkan hasil analisis dan pembahasan, maka dapat ditarik kesimpulan yang sebagai berikut:

1.Total biaya proyek dalam kondisi normal ialah sebesar Rp.12.764.000.000.00 setelah dilakukan percepatan menggunakan metode crashing dengan menerapkan sistem shift kerja (shift pagi dan shift malam) di dapat biaya sebesar Rp.12.971.000.000.00 atau lebih mahal dari biaya proyek pada kondisi normal di karenakan adanya penambahan upah pada saat pekerjaan shift dilakukan.

2.Dari kesimpulan nomor 1 dapat diambil kesimpulan kembali bahwa dengan menerapkan sistem shift kerja (shift pagi dan shift malam) merupakan alternatif program crashing yang lebih efektif menghemat durasi pekerjaan metode ini dapat mengurangi jumlah durasi waktu yang awalnya adalah 197 hari menjadi 173 hari, maka didapat pengurangan durasi waktu sebnyak 24 hari.

\section{REFERENSI}

[1] Arija, W. F. (2017). Digital Digital Repository Repository Universitas Universitas Jember Jember Digital Digital Repository Repository Universitas Universitas Jember Jember Text Mining pada Media Sosial Twitter.

[2] Caesaron, D., \& Thio, A. (2015). Analisa penjadwalan waktu dengan metode jalur kritis dan pert pada proyek pembangunan ruko (jl. pasar lama no.20, glodok). 8(2), 59-82.

[3] Frederika, A. (2010). ANALISIS PERCEPATAN PELAKSANAAN DENGAN MENAMBAH JAM KERJA OPTIMUM PADA PROYEK KONSTRUKSI (STUDI KASUS: PROYEK PEMBANGUNAN SUPER VILLA, PETI TENGET-BADUNG). Jurnal Ilmiah Teknik Sipil, 14(2).

[4] Hendriputri, A. A. (2018). PERCEPATAN JADWAL (CRASHING) MENGGUNAKAN SISTEM SHIFT DENGAN ANALISIS PDM (PRECENDENCE DIAGRAMMING METHOD) (CRASHING USING SHIFT SYSTEM WITH PDM (PRECEDENCE DIAGRAMMING METHOD) ANALYSIS). Jurnal Ilmiah Teknik Sipil, 1.

[5] Irwan, H. (2019). Crash Program Jalur Kritis Dengan Cara Overlapping (Study Review). Sigma Teknika, 2(1), 
14.

https://doi.org/10.33373/sigma.v2i1.1 671

[6] Kastawan Mandala, R. W. K. W. (2018). PENERAPAN NETWORK PLANNING PADA PROYEK PEMBANGUNAN PERUMAHAN MUTIARA RESIDENCE DI DESA PENGAMBENGAN KABUPATEN JEMBRANA Rini Wijaya Kusuma Wardhani $^{1}$ Kastawan Mandala ${ }^{1}$, ${ }^{2}$ Fakultas Ekonomi dan Bisnis Universitas Udayana , Bali, Indonesia PENDAHULUAN Provi. 7(12), 6731-6758. network planning, critical path method, critical path.\%0A6731

[7] Nuhuyanan, T. T., \& Sumarningsih, T. (2018). Percepatan proyek pembangunan pengadilan negeri wonosari dengan metode shift kerja. Jurnal Ilmiah Teknik Sipil.

[8] Oka Suputra, I. (2011). Penjadwalan Proyek Dengan Precedence Diagram Method (Pdm) Dan Ranked Position Weight Method (Rpwm). Jurnal Ilmiah Teknik Sipil, 15(1), 18-28.

[9] Qomariyah, S., \& Hamzah, F. (2013). Analisis Network Planning Dengan Cpm (Critical Path Method) Dalam Rangka Efisiensi Waktu Dan Biaya Proyek. 1(4), 408-416.

[10] Rama, R., Elga, D., Wibowo, A., \& Kistiani, F. (2016). Analisa Percepatan Proyek Metode Crash Program Studi Kasus: Proyek Pembangunan Gedung Mixed Use Sentraland. Jurnal Karya Teknik Sipil, 5, 148-158.

[11] Setiawan, B. B., Teknik, J., Universitas, S., Jakarta, M., Jurusan, D., Sipil, T., \& Muhammadiyah, U. (2012). Analisis Pertukaran Waktu Dan Biaya Dengan Metode Time Cost Trade Off ( Tcto ) Pada Proyek
Pembangunan Gedung Di Jakarta. Jurnal Konstruksia, 4(1), 25-34.

[12]

Soeharto, I. (1999). Manajemen Proyek (Dari Konseptual Sampai Operasional (2nd ed.). Erlangga.

[13] Supriyanto. (2019). Optimasi waktu /proses produksi DI PT. SUMIDEN SINTERED COMPONENT INDONESIA DENGAN TEKNIK ANALISA NETWORK/PERT DAN METODE SMED. 53(9), 1689-1699. https://doi.org/10.1017/CBO9781107 415324.004 